Article

\title{
Distributions and Risk Assessment of the Natural Radionuclides in the Soil of Shoubra El Kheima, South Nile Delta, Egypt
}

\author{
Randa Osman ${ }^{1}$, Yehia H. Dawood ${ }^{2}$, Ahmed Melegy ${ }^{1}$, Mohamed S. El-Bady ${ }^{1}$, Ahmed Saleh ${ }^{3, *(D)}$ \\ and Ahmed Gad ${ }^{2, *(D)}$ \\ 1 National Research Centre, Geological Sciences Department, Dokki, Cairo 12622, Egypt; \\ ro.abdel-magied@nrc.sci.eg (R.O.); aa.melegy@nrc.sci.eg (A.M.); ms.el-bady@nrc.sci.eg (M.S.E.-B.) \\ 2 Geology Department, Faculty of Science, Ain Shams University, Cairo 11566, Egypt; \\ yhdawood@sci.asu.edu.eg \\ 3 National Research Institute for Astronomy and Geophysics, Cairo 11421, Egypt \\ * Correspondence: ahmed.saleh@nriag.sci.eg (A.S.); A.gad@sci.asu.edu.eg (A.G.)
}

Citation: Osman, R.; Dawood, Y.H. Melegy, A.; El-Bady, M.S.; Saleh, A.; Gad, A. Distributions and Risk Assessment of the Natural

Radionuclides in the Soil of Shoubra El Kheima, South Nile Delta, Egypt. Atmosphere 2022, 13, 98. https:// doi.org/10.3390/atmos13010098

Academic Editor: Amin Shahrokhi

Received: 20 December 2021

Accepted: 5 January 2022

Published: 8 January 2022

Publisher's Note: MDPI stays neutral with regard to jurisdictional claims in published maps and institutional affiliations.

Copyright: (C) 2022 by the authors. Licensee MDPI, Basel, Switzerland. This article is an open access article distributed under the terms and conditions of the Creative Commons Attribution (CC BY) license (https:// creativecommons.org/licenses/by/ $4.0 /)$.

\begin{abstract}
Due to heightening concern about radiation hazards protection, activity concentrations of ${ }^{226} \mathrm{Ra},{ }^{232} \mathrm{Th},{ }^{40} \mathrm{~K}$ in forty soil samples collected from Shoubra El Kheima in the South Nile Delta were measured using gamma-ray spectrometry. The mean activity concentrations of ${ }^{226} \mathrm{Ra}$ and ${ }^{40} \mathrm{~K}$ were higher in $20 \%$ of the considered samples than the world average values. A comprehensive comparison with up-to-date data was carried out. Spatial distribution maps of the measured radionuclides and radiological parameters were generated. The distributions of natural radionuclides were influenced by the soil organic matter, clay content, and scavenger metals oxides, as well as differences in the physical and chemical attributes and solubility of these radionuclides. The results revealed that industrial activity and agricultural practices in the study area caused an incremental increase in ${ }^{226} \mathrm{Ra}$ and ${ }^{40} \mathrm{~K}$ activity concentrations. It can be deduced that although there are intensive industrial activities in this area, the natural radiation that comes from the soil is normal and does not pose a significant radiological hazard to the public. The natural radioactivity of soil in this area needs to be monitored periodically to prevent unnecessary radiation exposure to inhabitants.
\end{abstract}

Keywords: soil radioactivity; radium; thorium; radiation hazards; excess lifetime cancer risk; Nile Delta

\section{Introduction}

There is a growing consensus among scientists, international organizations, decisionmakers, and laypersons that human exposure to external and internal (inhalation and ingestion) radiation is a critical and inevitable environmental issue. Even though all living organisms are exposed to natural (cosmic sources and background terrestrial radiation) and artificial ionizing radiation sources, most radiation absorbed by the world's population is from natural sources [1-3]. The primordial radioactive isotopes ${ }^{238} \mathrm{U}$ and ${ }^{232} \mathrm{Th}$, their decay products, and ${ }^{40} \mathrm{~K}$ are present at different concentrations in all environmental compartments and produce significant human exposure [1,4,5]. These radioactive elements naturally make their way into the soil, surface water, and groundwater through different earth surface processes [2,6]. Their concentrations increase above normal levels in association with anthropogenic activities, such as the testing of nuclear weapons [2], mining, the production of industrial minerals and materials [7-11], fossil fuel production and combustion [12-14], and the use of phosphate and potassium sulfate fertilizers [15-17].

Soil represents the prime source of continuous radiation outdoor exposure to humans. Although soil radionuclide contents are directly linked to those of the parent rock [9,18-20], soil formation processes could contribute to changes in the soil's radionuclide contents by 
addition, loss, and translocation $[3,18,21]$. Soil physicochemical attributes such as texture, $\mathrm{pH}$, organic matter content $(\mathrm{OM} \%)$, and concentration of the scavenger metals Fe and Mn have a remarkable influence on the distribution and mobility of radionuclides in the soil [16,18,22-24].

Once present in the soil, natural radionuclides are transferred to biological systems and the food chain [25-27]. Therefore, the soil in common is a significant indicator of radiological contamination and allows researchers to uncover areas of possible radiotoxicity [28]. Continuous measurement of radiation levels in soil and associated radiological hazards can be used to discover and reliably predict negative changes in environmental radioactivity inadvertently caused by human activities [1].

Fast population growth in Egypt, especially in the Nile Delta region, has undoubtedly led to an increase in industrial and commercial activities. Unorganized urbanization and industrialization over the fertile soil of the Nile Delta have exacerbated the creation of environmental and public health problems of vast proportions $[29,30]$. Therefore, the specific aims of the present work are: (i) Measuring the activity concentration and distribution of natural radionuclides $\left({ }^{226} \mathrm{Ra},{ }^{232} \mathrm{Th}\right.$, and $\left.{ }^{40} \mathrm{~K}\right)$ in soil with various land uses in a highly industrialized area of the South Nile Delta; (ii) Identifying soil attributes that influence the distribution of these radionuclides; (iii) Assessing the human radiation doses and concomitant cancer risk.

\section{Materials and Methods}

\subsection{Study Area}

Shoubra El Kheima is located in the southeast of the Nile Delta between longitude $31^{\circ} 14^{\prime} 7.7^{\prime \prime}-31^{\circ} 17^{\prime} 45^{\prime \prime} \mathrm{E}$ and latitude $30^{\circ} 6^{\prime} 22.4^{\prime \prime}-30^{\circ} 9^{\prime} 37.5^{\prime \prime} \mathrm{N}$ (Figure 1). It belongs to Qalyobia governorate and occupies an area of about $30 \mathrm{~km}^{2}$. Besides agricultural activity, this area suffers from intensified industrial activities such as glass, crystal, ceramic, and brick production, as well as chemical, textile, and ferrous and nonferrous metallurgical industries, in addition to two large power plants.

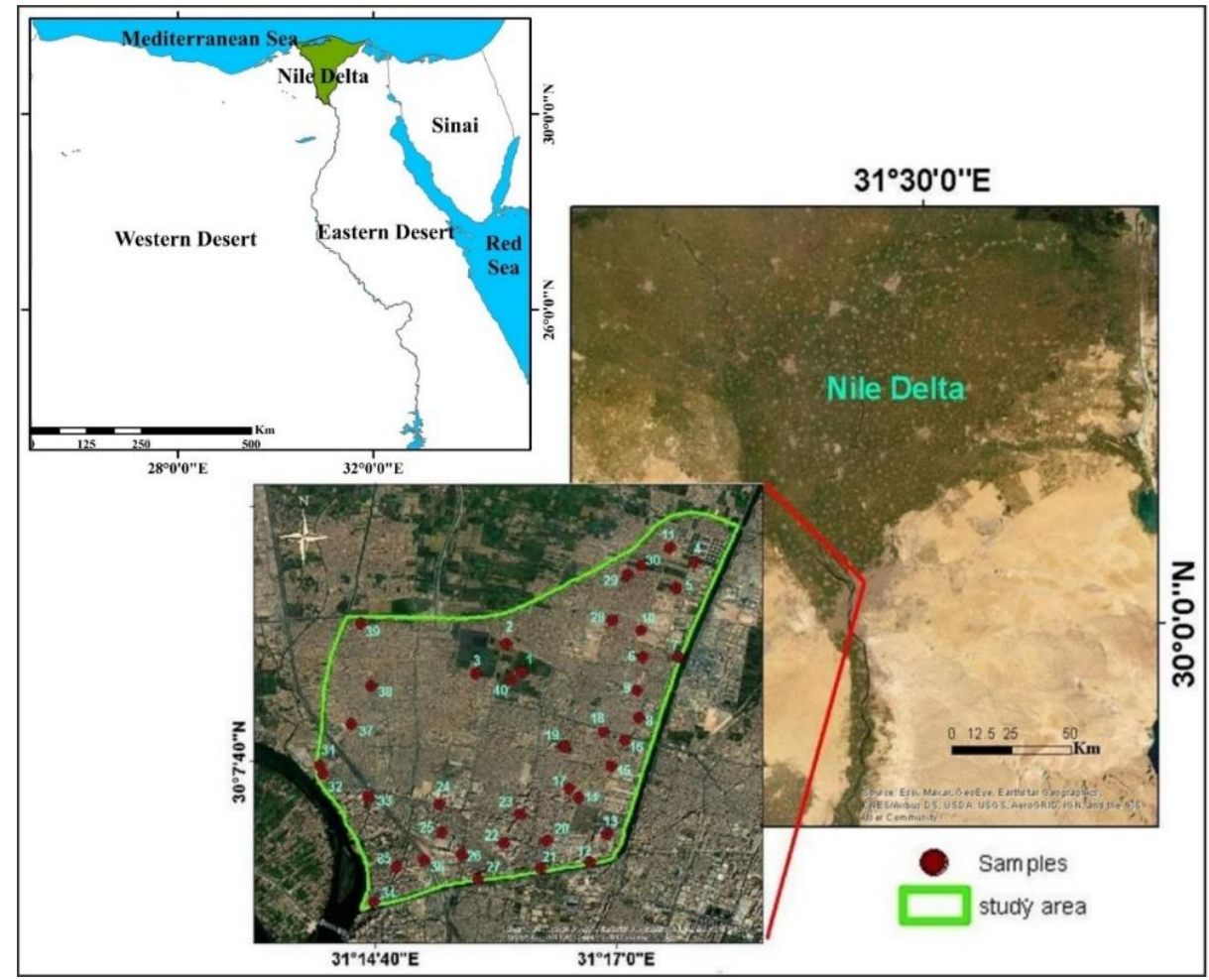

Figure 1. Satellite images showing the location of the study area and sampling sites. 


\subsection{Sampling}

Forty surface soil samples (up to a depth of $25 \mathrm{~cm}$ ) were collected from different landuse types (agricultural, urban, and industrial) using a clean stainless-steel shovel. After manual elimination of pebble stones, gravel, and any plant debris, a $2 \mathrm{~kg}$ soil sample was collected from each site in a separate, neat, dust-free, labeled, and sealed polyethylene bag.

\subsection{Sample Treatment and Analysis}

Samples were air-dried for 10 days with continuous rotation in a controlled environment to avoid cross-contamination; representative sub-samples were obtained by coning and quartering. Soil samples were taken and passed through a $2 \mathrm{~mm}$ sieve to remove large particles.

The $\mathrm{pH}$ values were determined with a glass electrode in an aqueous suspension of distilled water (1:2.5) using a $\mathrm{pH}$ meter (HANA). Soil organic matter content was measured by loss on ignition following the procedure adopted by Van Reeuwijk [31]. Soil texture classes were measured using wet and dry sieving; pipette analysis followed the procedure adopted by Lewis and McConchie [32].

Clay mineralogical composition was identified using X-ray diffraction analysis accomplished by using a BRUKER-D8 Advance diffractometer with $\mathrm{Ni}$ filter, $\mathrm{Cu}-\mathrm{K} \alpha$ radiation available at the Central Metallurgical Research and Development Institute, Egypt. Instrument settings were $40 \mathrm{Kv}$ and $40 \mathrm{~mA}$ potential, scanning speed of $0.02^{\circ} / \mathrm{S}$, and the $2 \theta$ ranged between 4 to $60^{\circ}$.

The XRF analysis was carried out for the powder $(<74 \mu \mathrm{m})$ samples using X-ray fluorescence equipment PW 2404 with five analyzing crystals. The concentrations of the analyzed major elements (oxides \%) were calculated using the software Super Q and Semi Q programs, with an accuracy of $99.99 \%$ and a confidence limit of $96.7 \%$.

Homogenized soil samples were weighed and sieved (125 $\mu \mathrm{m}$ mesh size). The meshed samples were transformed into a standard Marinelli container $(100 \mathrm{~mL})$ and sealed for a period of about 4 weeks before analysis. This typically allows the in-growth of uranium and thorium decay products to prevent the escape of the radiogenic gases ${ }^{222} \mathrm{Rn}$ and ${ }^{220} \mathrm{Rn}$ and allows secular equilibrium between ${ }^{226} \mathrm{Ra},{ }^{232} \mathrm{Th}$, and their daughter products [33].

The ${ }^{226} \mathrm{Ra},{ }^{232} \mathrm{Th}$, and ${ }^{40} \mathrm{~K}$-specific activity concentrations in the collected soil samples were measured by gamma-ray spectrometry. A properly calibrated gamma-ray spectrometer of a 3" $\times 3$ " $\mathrm{NaI}(\mathrm{Tl})$ scintillation detector was used. The detector was adequately protected by a $0.6 \mathrm{~cm}$ thickness of cylindrical copper for protection against induced X-rays, and a chamber of lead bricks for isolation from the environmental radiations, with a $5 \mathrm{~cm}$ thick lead protection cover. The detector was connected to a Tennelec high-voltage power supply with HV digital display and a Nuclear Enterprises main shaping amplifier. It was also connected to a Nuclease PCA-8000 computer-based (8192) multichannel analyzer with high-level technical operation functionality and color graphical display of spectra. Energy calibration of the detector was performed using standard point sources $\left({ }^{137} \mathrm{Cs}\right.$ and ${ }^{60} \mathrm{Co}$ ). Each sample was counted for $1000 \mathrm{~s}$. Further details for precisely calculating activity concentration can be obtained elsewhere [9,34-36].

\subsection{Radiation Hazard Indices Calculation}

To objectively assess the external radiation hazards due to the activity concentration of the examined radionuclides in the study area soils, the quantities such as Radium Equivalent Activity Index ( $\left(\mathrm{Ra}_{\mathrm{eq}}\right)$ (Equation (1)), External Hazard Index $\left(\mathrm{H}_{\mathrm{ex}}\right)$ (Equation (2)), Absorbed Dose Rate (D) (Equation (3)), and Annual Effective Dose (AEDE) (Equation (4)) were calculated from the activity concentrations of ${ }^{226} \mathrm{Ra},{ }^{232} \mathrm{Th}$, and ${ }^{40} \mathrm{~K}$. Excess Lifetime Cancer Risk (ELCR) (Equation (5)) was also calculated to derive a more reasonable and safe conclusion. The descriptions and adopted formulas of the calculated external hazard indices are summarized in Table 1. 
Table 1. Summary of the external hazard radiological parameters.

\begin{tabular}{|c|c|c|c|c|c|}
\hline S/N & Radiological Parameters & & Units & Safety Criterion & References \\
\hline 1 & $\begin{array}{l}\text { Radium Equivalent Activity Index }\left(\mathrm{Ra}_{\mathrm{eq}}\right) \\
\qquad \mathrm{Ra}_{\mathrm{eq}}=\mathrm{C}_{\mathrm{Ra}}+1.43 \mathrm{C}_{\mathrm{Th}}+0.77 \mathrm{C}_{\mathrm{K}}\end{array}$ & (1) & $\mathrm{Bq} \mathrm{kg}{ }^{-1}$ & $<370 \mathrm{~Bq} \mathrm{~kg}^{-1}$ & {$[1,37]$} \\
\hline 2 & $\begin{array}{l}\text { External Radiation Hazard Index }\left(\mathrm{H}_{\mathrm{ex}}\right) \\
\qquad \mathrm{H}_{\mathrm{ex}}=\frac{\mathrm{C}_{\mathrm{Ra}}}{370}+\frac{\mathrm{C}_{\mathrm{Th}}}{259}+\frac{\mathrm{C}_{\mathrm{K}}}{4810}\end{array}$ & $(2)$ & - & $<1$ & {$[1,38]$} \\
\hline 3 & $\begin{aligned} & \text { Air Absorbed Dose Rate (D) } \\
\mathrm{D}= & 0.462 \mathrm{C}_{\mathrm{Ra}}+0.604 \mathrm{C}_{\mathrm{Th}}+0.0417 \mathrm{C}_{\mathrm{K}}\end{aligned}$ & (3) & nGy $\mathrm{h}^{-1}$ & $<57 \mathrm{nGy} \mathrm{h}^{-1}$ & [1] \\
\hline 4 & $\begin{array}{c}\text { Annual Effective Dose Equivalent (AEDE) } \\
\text { AEDE }=\mathrm{D} \times \mathrm{T} \times \mathrm{DCF} \times \mathrm{F}_{\mathrm{O}} \times 10^{-6}\end{array}$ & $(4)$ & mSv year $^{-1}$ & $<0.07 \mathrm{mSv}$ year $^{-1}$ & [1] \\
\hline 5 & $\begin{array}{c}\text { Excess Lifetime Cancer Risk }(\text { ELCR }) \\
\mathrm{ELCR}=\mathrm{AEDE} \times \mathrm{DL} \times \mathrm{RF}\end{array}$ & (5) & - & $<0.29 \times 10^{-3}$ & {$[4,39]$} \\
\hline
\end{tabular}

$\mathrm{C}_{\mathrm{Ra}}, \mathrm{C}_{\mathrm{Th}}$, and $\mathrm{C}_{\mathrm{K}}$ are the activity concentrations of ${ }^{226} \mathrm{Ra}^{232} \mathrm{Th}$, and ${ }^{40} \mathrm{~K}$ in $\left(\mathrm{Bq} \mathrm{kg}{ }^{-1}\right)$, respectively. $\mathrm{T}$ is the time being $8760 \mathrm{~h} \mathrm{y}^{-1}$, DCF is the dose conversion factor of $0.7 \mathrm{SvGy}^{-1}, \mathrm{~F}_{\mathrm{O}}$ is the outdoor occupancy factor of 0.2 for inhabitants [1]. DL is the duration of lifetime (70 years), and RF is the cancer risk factor used for public as $0.05 \mathrm{~Sv}^{-1}[40]$.

\subsection{Data Treatment and Statistical Analysis}

The geographic information system (GIS) technique was utilized to construct sampling locations and spatial distribution maps of the measured radionuclides using Arc GIS (version $10.3 ; 2014$ ) with a natural neighbor as a raster interpolation technique. Descriptive statistics and boxplots were presented by OriginLab (version OriginPro; 2021). Soil samples were classified using the USDA classification ternary chart [41]. Bivariate X-Y plots with the coefficient of determination $R^{2}$ of linear fit were calculated and illustrated by OriginLab. Multivariate Pearson's correlation coefficient matrix (PCC) was carried out with IBM SPSS (version 20; 2012). All statistical evaluations were calculated to define correlation between the examined radionuclides and soil properties and their controlling factors.

\section{Results and Discussion}

\subsection{Soil Characteristics}

The physicochemical properties of the considered soil samples are presented in Table 2. These soil samples fall in moderately alkaline soil (7:9). Organic matter content (OM\%) varies from $1.20 \%$ to $8.88 \%$, with mean values of $6.05 \%, 3.64 \%$, and $4.03 \%$ for agricultural, urban, and industrial soil, respectively. The textural properties of the considered soil samples show a marked variation in clay content and soil class. Most of the agricultural soil samples are classified as clay, while urban and industrial soil samples are varied in their classification from clayey to loamy sand (Figure 2). The texture of the agricultural soil reflects its origin as Nile Delta soil [42], while urban and industrial soils were affected to a large extent by industrialization and urbanization, and transportation or mixing with external particles [30].

There was no observed significant variation in the major oxides' concentrations between different soil types, except for $\mathrm{SiO}_{2}$, which is higher in urban and industrial than agricultural soil, reflecting the sandy texture of these soils. Otherwise, the highest $\mathrm{Al}_{2} \mathrm{O}_{3}$ contents were recorded in the agricultural soil samples, indicative of their high clay content.

Representative samples with high clay content were examined qualitatively using $X$-ray Diffractometry. The examined clay fractions are dominated by montmorillonite and kaolinite minerals. Illite mineral is also recorded in some samples (Figure 3).

\subsection{Activity Concentrations}

In general, the activity concentrations of urban and industrial soils have the order ${ }^{40} \mathrm{~K}>{ }^{226} \mathrm{Ra}>{ }^{232} \mathrm{Th}$. Conversely, the activity concentrations in the agricultural soil have the order ${ }^{40} \mathrm{~K}>{ }^{232} \mathrm{Th}>{ }^{226} \mathrm{Ra}$. As seen in Table 2, the agricultural soil samples contain higher activity concentrations of ${ }^{226} \mathrm{Ra},{ }^{232} \mathrm{Th}$, and ${ }^{40} \mathrm{~K}$ than the urban and industrial soil samples (Figure 4). 
Table 2. Descriptive statistics of soil physicochemical parameters and oxides (\%) and measured radionuclides $\left(\mathrm{Bq} \mathrm{Kg}^{-1}\right)$ in different land-use soil samples.

\begin{tabular}{|c|c|c|c|c|c|c|c|c|c|c|c|c|c|c|c|}
\hline Soil Land & Use & $\mathrm{pH}$ & OM & Sand & Silt & Clay & $\mathrm{SiO}_{2}$ & $\mathrm{Al}_{2} \mathrm{O}_{3}$ & $\mathrm{Fe}_{2} \mathrm{O}_{3}$ & $\mathrm{MnO}$ & MgO & $\mathrm{CaO}$ & ${ }^{226} \mathrm{Ra}$ & ${ }^{232} \mathrm{Th}$ & ${ }^{40} \mathrm{~K}$ \\
\hline \multirow{4}{*}{$\begin{array}{l}\text { Agricultural } \\
\qquad N=16\end{array}$} & Min & 7.92 & 4.23 & 2.70 & 20.60 & 8.70 & 41.50 & 15.40 & 7.50 & 0.10 & 1.80 & 3.10 & UDL & 20.20 & 103.29 \\
\hline & $\operatorname{Max}$ & 8.78 & 8.88 & 37.33 & 43.90 & 61.00 & 50.50 & 21.90 & 9.50 & 0.24 & 2.60 & 6.50 & 33.30 & 32.32 & 635.39 \\
\hline & Mean & 8.42 & 6.05 & 12.98 & 27.43 & 48.85 & 45.44 & 18.23 & 8.21 & 0.17 & 2.14 & 4.77 & 18.73 & 26.01 & 337.06 \\
\hline & $\begin{array}{l}\text { Std. } \\
\text { D. }\end{array}$ & 0.22 & 1.23 & 7.66 & 5.85 & 11.92 & 2.40 & 2.20 & 0.54 & 0.03 & 0.19 & 0.83 & 11.26 & 4.89 & 141.61 \\
\hline \multirow{4}{*}{$\begin{array}{l}\text { Urban } \\
N=10\end{array}$} & Min & 8.18 & 1.43 & 6.94 & 7.98 & 6.44 & 49.50 & 8.89 & 2.58 & 0.03 & 0.88 & 3.20 & 11.10 & 8.08 & 71.99 \\
\hline & $\operatorname{Max}$ & 8.78 & 5.46 & 72.52 & 39.99 & 55.00 & 73.80 & 17.80 & 8.60 & 0.13 & 2.10 & 6.29 & 44.40 & 24.24 & 422.55 \\
\hline & Mean & 8.45 & 3.64 & 35.26 & 26.84 & 29.86 & 56.30 & 14.03 & 7.27 & 0.10 & 1.62 & 4.95 & 21.09 & 14.95 & 233.19 \\
\hline & $\begin{array}{l}\text { Std. } \\
\text { D. }\end{array}$ & 0.22 & 1.27 & 23.29 & 11.11 & 17.28 & 7.67 & 3.46 & 1.77 & 0.04 & 0.33 & 0.96 & 9.72 & 4.68 & 116.86 \\
\hline \multirow{4}{*}{$\begin{array}{l}\text { Industrial } \\
\qquad N=14\end{array}$} & Min & 7.65 & 1.20 & 19.19 & 2.39 & 8.70 & 47.60 & 8.10 & 3.20 & 0.01 & 0.50 & 3.50 & UDL & UDL & 9.39 \\
\hline & $\operatorname{Max}$ & 8.96 & 6.63 & 84.25 & 35.97 & 41.80 & 76.20 & 21.00 & 10.40 & 0.26 & 2.75 & 6.50 & 33.30 & 28.28 & 697.99 \\
\hline & Mean & 8.32 & 4.03 & 50.57 & 22.05 & 18.46 & 55.91 & 13.41 & 7.60 & 0.15 & 1.71 & 5.17 & 20.61 & 15.01 & 240.12 \\
\hline & $\begin{array}{l}\text { Std. } \\
\text { D. }\end{array}$ & 0.34 & 1.47 & 17.96 & 11.36 & 8.89 & 7.93 & 3.68 & 1.91 & 0.08 & 0.58 & 0.80 & 9.60 & 8.74 & 202.92 \\
\hline \multirow{4}{*}{$\begin{array}{l}\text { All Samples } \\
\qquad N=40\end{array}$} & Min & 7.65 & 1.20 & 2.70 & 2.39 & 6.44 & 41.50 & 8.10 & 2.58 & 0.01 & 0.50 & 3.10 & UDL & UDL & 9.39 \\
\hline & Max & 8.96 & 8.88 & 84.25 & 43.90 & 61.00 & 76.20 & 21.90 & 10.40 & 0.26 & 2.75 & 6.50 & 44.40 & 32.32 & 697.99 \\
\hline & Mean & 8.39 & 4.74 & 31.71 & 25.40 & 33.47 & 51.82 & 15.49 & 7.76 & 0.14 & 1.86 & 4.96 & 19.98 & 19.39 & 277.16 \\
\hline & $\begin{array}{c}\text { Std. } \\
\text { D. }\end{array}$ & 0.27 & 1.69 & 23.03 & 9.53 & 18.20 & 8.04 & 3.79 & 1.49 & 0.06 & 0.45 & 0.85 & 10.12 & 8.34 & 164.47 \\
\hline
\end{tabular}

$\mathrm{UDL}=$ Under detection limit.

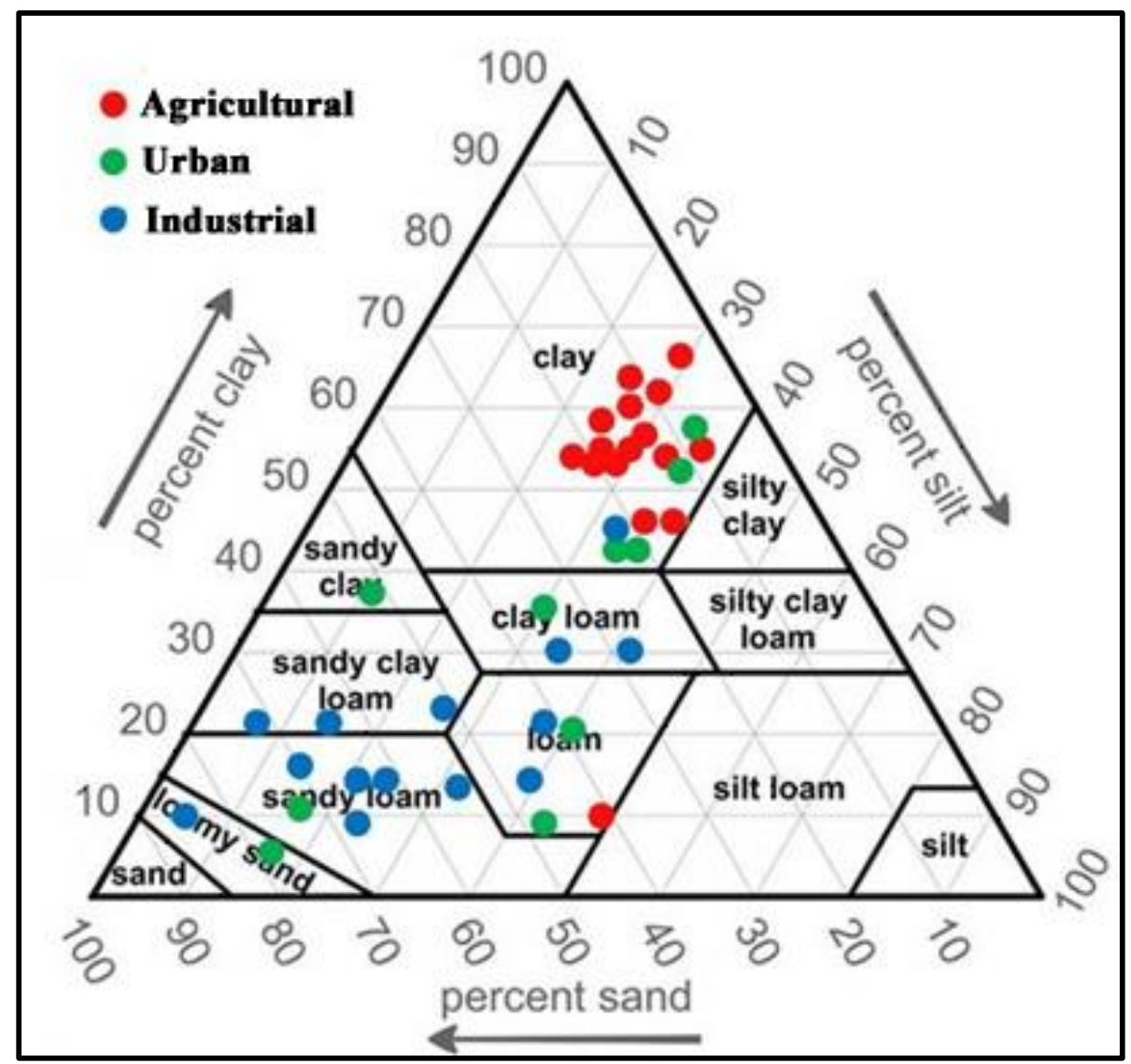

Figure 2. Classification of the studied soil samples [41]. 


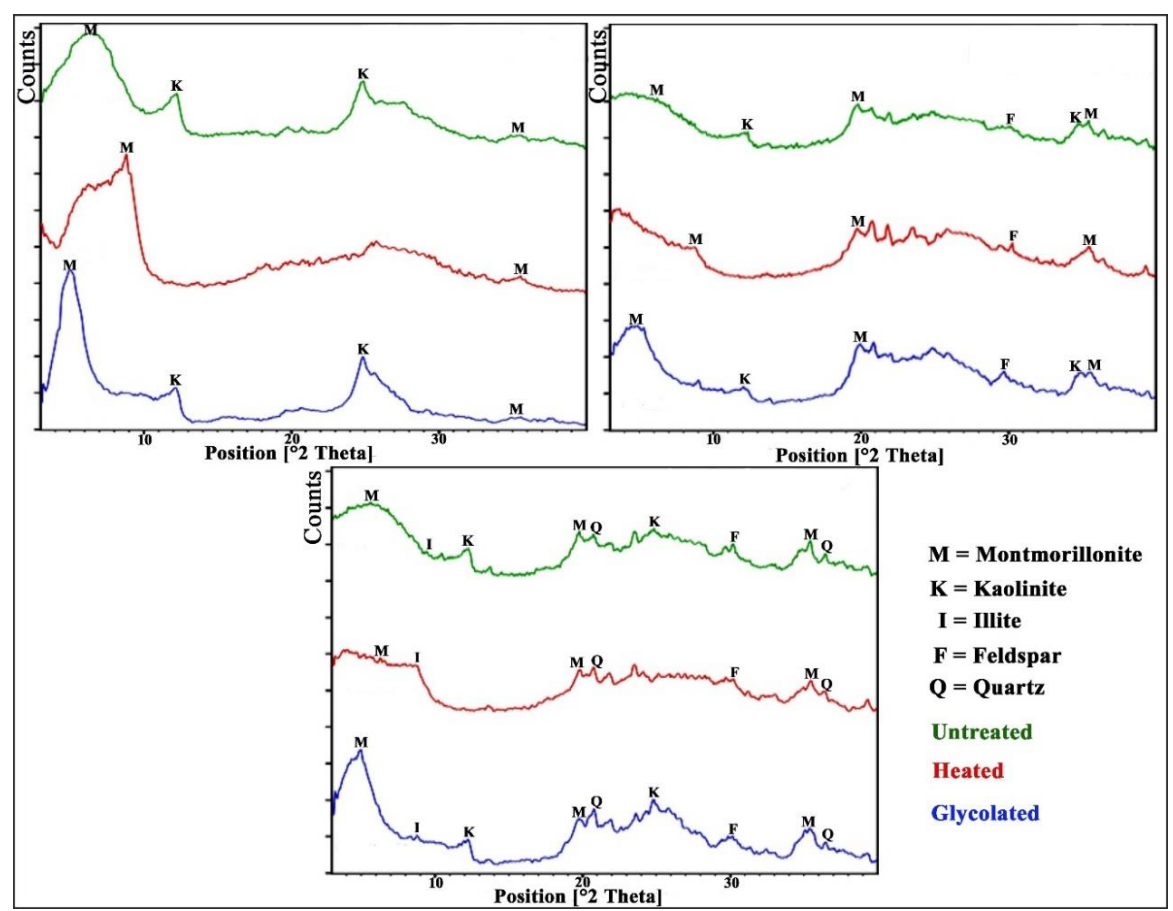

Figure 3. X-ray diffractograms of clay fraction.

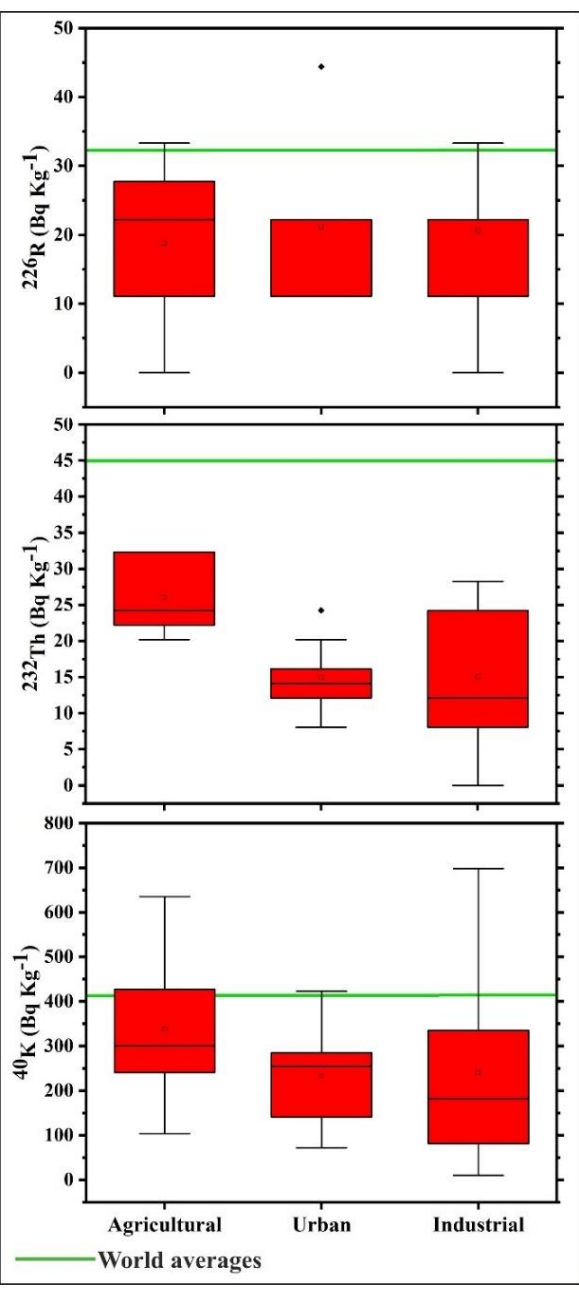

Figure 4. Boxplot of ${ }^{226} \mathrm{Ra},{ }^{232} \mathrm{Th}$, and ${ }^{40} \mathrm{~K}$ activity concentrations in the studied soil. 
The GIS-based frequency distribution maps of ${ }^{226} \mathrm{Ra},{ }^{232} \mathrm{Th}$, and ${ }^{40} \mathrm{~K}$ are presented in Figure 5 . The ${ }^{232} \mathrm{Th}$ high activity concentration values are recorded in the northern parts of the study area. ${ }^{226} \mathrm{Ra}$ and ${ }^{40} \mathrm{~K}$ activity concentrations increase in the eastern parts near industrial complexes.

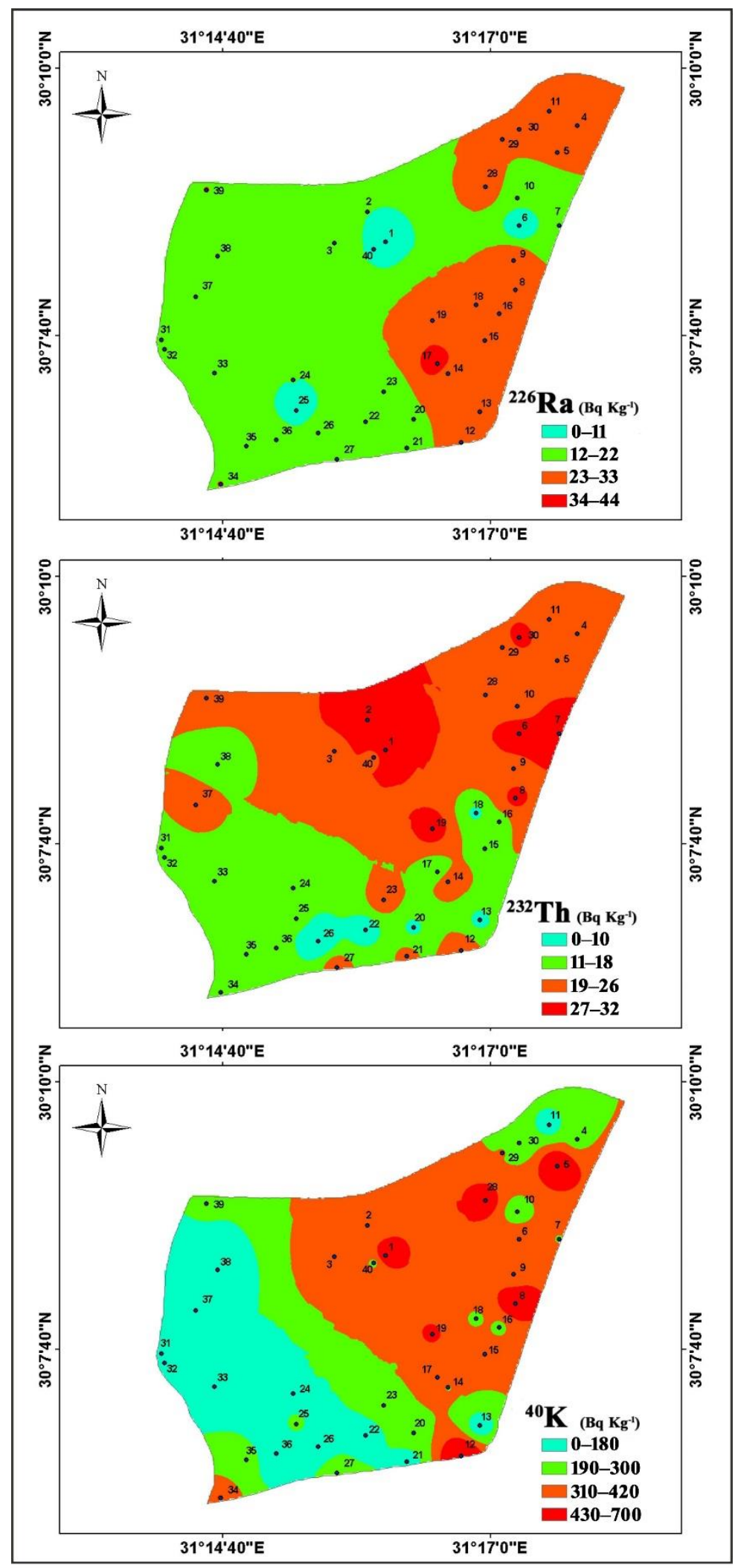

Figure 5. Spatial distribution maps of ${ }^{226} \mathrm{Ra},{ }^{232} \mathrm{Th}$, and ${ }^{40} \mathrm{~K}$ activity concentrations. 
The mean activity concentrations of ${ }^{226} \mathrm{Ra}$ and ${ }^{40} \mathrm{~K}$ are higher in $20 \%$ of the studied samples than the world's average values (32, 45, and $412 \mathrm{~Bq} \mathrm{~kg}^{-1}$, respectively) [4] (Figure 4). This indicates that the activity concentrations of ${ }^{226} \mathrm{Ra}$ and ${ }^{40} \mathrm{~K}$ were affected to varying degrees by the anthropogenic activities. Conversely, ${ }^{232} \mathrm{Th}$ activity concentrations are lower than those of the world average.

${ }^{232} \mathrm{Th}$ naturally exists in soil, and its activity concentration in phosphatic fertilizers is extremely small [43]; its relatively low concentration in the studied soil could be attributed to soil parent materials $[12,16]$. In slightly and moderately alkaline soils, ${ }^{226} \mathrm{Ra}$ is mostly present as an available form and easily leached by waters [44]. On the contrary, ${ }^{232} \mathrm{Th}$ remains part of the resistance to weathering mineral constituents $[12,21,45]$. It is understood that ${ }^{40} \mathrm{~K}$ in the earth's crust and soil is an order of magnitude higher than that of ${ }^{226} \mathrm{Ra}$ and ${ }^{232} \mathrm{Th}[3,26,46]$. The long-continuous application of phosphate and/or potassium sulfate fertilizers can redistribute and raise ${ }^{226} \mathrm{Ra}$ and ${ }^{40} \mathrm{~K}$ concentrations in soils [17,47].

Results obtained for the activity concentration of primordial radionuclides $\left({ }^{226} \mathrm{Ra}\right.$, ${ }^{232} \mathrm{Th}$, and ${ }^{40} \mathrm{~K}$ ) in the present study have been comprehensively compared with available up-to-date data for many regions in Egypt and many countries around the world in the literature (Table 3).

Table 3. Comparison of ${ }^{226} \mathrm{Ra},{ }^{232} \mathrm{Th}$, and ${ }^{40} \mathrm{~K}$ mean activity concentration in soil samples reported for different regions in Egypt and worldwide.

\begin{tabular}{|c|c|c|c|c|c|}
\hline Location & Samples & ${ }^{226} \mathrm{Ra}$ & ${ }^{232} \mathrm{Th}$ & ${ }^{40} \mathrm{~K}$ & References \\
\hline \multicolumn{6}{|c|}{ Egypt } \\
\hline South Nile Delta (Shoubra) & $N=40$ & 19.98 & 19.39 & 277.16 & Present study \\
\hline Middle Nile Delta (Dakahlia) & $N=25$ & 43.00 & 54.00 & 183.00 & [25] \\
\hline Southeastern Nile Delta & $N=36$ & 35.50 & 23.60 & 266.40 & [16] \\
\hline Mediterranean Sea coast & $N=38$ & 25.18 & 11.22 & 159.16 & [28] \\
\hline Upper Egypt (Assiut) & $N=15$ & 49.45 & 59.11 & 137.85 & [9] \\
\hline Upper Egypt (EL Minya) & $N=174$ & 17.53 & 10.16 & 183.08 & [24] \\
\hline Upper Egypt (Qena) & $N=32$ & 13.70 & 12.30 & 1233.00 & [22] \\
\hline \multicolumn{6}{|c|}{ Worldwide } \\
\hline Antarctica (Larsemann) & $N=20$ & 33.00 & 199.00 & 1150.00 & {$[5]$} \\
\hline Armenia (Yerevan) & $N=51$ & 45.69 & 37.25 & 423.68 & [20] \\
\hline Bangladesh (Chittagong) & $N=10$ & 45.00 & 51.00 & 423.00 & [12] \\
\hline $\begin{array}{l}\text { Bosnia and Herzegovina (Tuzla and } \\
\text { Lukavac) }\end{array}$ & $N=31$ & 32.00 & 32.00 & 331.00 & [48] \\
\hline Brazil (Fernando de Noronha) & $N=70$ & 62.00 & 82.00 & 179.00 & [21] \\
\hline China (Guangyao) & $N=30$ & 26.80 & 8.87 & 453.81 & [46] \\
\hline Cyprus & $N=37$ & 83.70 & 53.60 & 593.90 & [35] \\
\hline Georgia (Mtskheta-Mtianeti) & $N=17$ & 24.00 & 26.90 & 464.00 & [44] \\
\hline India (Karnataka) & $N=25$ & 28.07 & 21.58 & 237.68 & [36] \\
\hline Iraq (The-Qar) & $N=33$ & 12.89 & 15.54 & 297.22 & [14] \\
\hline Jordan (Amman) & $N=40$ & 29.00 & 35.50 & 265.70 & [49] \\
\hline Korea (Jeju Island) & $N=16$ & 32.40 & 35.60 & 314.00 & [3] \\
\hline Malaysia (Kelantan) & $N=36$ & 82.00 & 123.00 & 643.00 & [50] \\
\hline Nigeria (Zamfara) & $N=18$ & 19.00 & 23.00 & 269.00 & [10] \\
\hline Pakistan (Rawalpindi) & $N=14$ & 19.04 & 30.52 & 303.09 & [17] \\
\hline Saudi Arabia (Abha) & $N=13$ & 38.67 & 23.49 & 217.87 & [34] \\
\hline Tanzania (Iringa) & $N=12$ & 163.00 & 143.00 & 583.00 & [47] \\
\hline Turky (Istanbul) & $N=22$ & 30.40 & 36.60 & 524.50 & [51] \\
\hline Yemen (Delta Abyan) & $N=28$ & 33.15 & 77.25 & 1220.59 & [26] \\
\hline
\end{tabular}

The mean activity concentrations of ${ }^{226} \mathrm{Ra}\left(19.98 \mathrm{~Bq} \mathrm{~kg}^{-1}\right)$ and ${ }^{232} \mathrm{Th}\left(19.39 \mathrm{~Bq} \mathrm{~kg}{ }^{-1}\right)$ are lower than those from various regions in Egypt, with the exception of ${ }^{226} \mathrm{Ra}$, which showed high activity concentrations compared with those from El Minya [24] and Qena [22]; and ${ }^{232} \mathrm{Th}$, which showed high activity concentrations compared with those from the 
Mediterranean Sea coast [28], El Minya [24], and Qena [22]. On the other hand, the mean activity concentration of ${ }^{40} \mathrm{~K}\left(277.16 \mathrm{~Bq} \mathrm{~kg}^{-1}\right)$ is higher than all recorded values in Egypt, except those from Qena [22].

Compared to the mean values recorded in other countries worldwide, the mean activity concentrations of ${ }^{226} \mathrm{Ra}\left(19.98 \mathrm{~Bq} \mathrm{~kg}^{-1}\right)$ are lower than those from worldwide locations, with exceptions from Iraq [14], Nigeria [10], and Pakistan [17]. Likewise, ${ }^{232} \mathrm{Th}$ (19.39 Bq kg$\left.{ }^{-1}\right)$ is higher than those from China [46] and Iraq [14]. On the other side, ${ }^{40} \mathrm{~K}$ (277.16 Bq kg$\left.{ }^{-1}\right)$ is higher than those from Brazil [21], India [36], Jordan [49], Nigeria [10], and Saudi Arabia [34].

\subsection{Statistical Analysis}

Statistical PCC analyses among variables are presented in Table $4 .{ }^{232} \mathrm{Th}$ and ${ }^{40} \mathrm{~K}$ have positive correlations with OM content $(\mathrm{r}=0.550$ and $\mathrm{r}=0.370$; respectively), clay content $(\mathrm{r}=0.652$ and $\mathrm{r}=0.403$; respectively), and with each other $(\mathrm{r}=0.536)$ (Figure 6). In addition, they exhibit a positive correlation with $\mathrm{Al}_{2} \mathrm{O}_{3}$ and $\mathrm{MgO}$, which are mainly related to the aforementioned positive relation with clay content, which is dominated by montmorillonite and kaolinite. The observed positive relation between these two radionuclides and $\mathrm{Fe}_{2} \mathrm{O}_{3}$ and $\mathrm{MnO}$ can be attributed to the nature of $\mathrm{Fe}$ and Mn oxides as scavenger metals (Figure 7). ${ }^{232} \mathrm{Th}$ is similarly strongly absorbed by clay minerals and oxyhydroxides (Abedin et al. 2019). These relations sufficiently indicate that $\mathrm{OM}$ and clay content play a significant role in ${ }^{232} \mathrm{Th}$ and ${ }^{40} \mathrm{~K}$ distribution [12,22].

Table 4. Pearson's correlation coefficient for the studied variables $(n=40)$.

\begin{tabular}{|c|c|c|c|c|c|c|c|c|c|c|c|}
\hline Sand & Silt & Clay & $\mathrm{SiO}_{2}$ & $\mathrm{Al}_{2} \mathrm{O}_{3}$ & $\mathrm{Fe}_{2} \mathrm{O}_{3}$ & $\mathrm{MnO}$ & $\mathrm{MgO}$ & $\mathrm{CaO}$ & ${ }^{226} \mathrm{Ra}$ & ${ }^{232} \mathrm{Th}$ & ${ }^{40} \mathrm{~K}$ \\
\hline $\mathrm{OM}-0.717^{* *}$ & 0.360 * & $0.615 * *$ & $-0.743 * *$ & $0.513 * *$ & $0.479 * *$ & $0.454 * *$ & $0.521 * *$ & 0.042 & 0.032 & $0.550 * *$ & 0.370 * \\
\hline Sand 1 & $-0.582 * *$ & $-0.897 * *$ & $0.761 * *$ & $-0.570 * *$ & $-0.419^{* *}$ & $-0.402 *$ & $-0.617^{* *}$ & 0.088 & -0.072 & $-0.715^{* *}$ & -0.463 ** \\
\hline Silt & 1 & 0.172 & $-0.548 * *$ & 0.395 * & 0.329 * & 0.241 & $0.506^{* *}$ & 0.165 & 0.038 & 0.395 * & 0.286 \\
\hline Clay & & 1 & $-0.584^{* *}$ & $0.469 * *$ & 0.295 & 0.324 * & $0.446 * *$ & -0.234 & 0.064 & $0.652 * *$ & $0.403^{* *}$ \\
\hline $\mathrm{SiO}_{2}$ & & & 1 & -0.795 ** & $-0.692 * *$ & $-0.573 * *$ & -0.699 ** & -0.175 & -0.076 & $-0.683^{* *}$ & -0.470 ** \\
\hline $\mathrm{Al}_{2} \mathrm{O}_{3}$ & & & & 1 & $0.395^{*}$ & 0.309 & 0.383 * & -0.075 & 0.046 & $0.660 * *$ & $0.407 * *$ \\
\hline $\mathrm{Fe}_{2} \mathrm{O}_{3}$ & & & & & 1 & $0.443^{* *}$ & 0.368 * & 0.312 & -0.053 & 0.349 * & $0.358 *$ \\
\hline $\mathrm{MnO}$ & & & & & & 1 & $0.657^{* *}$ & 0.227 & 0.196 & 0.403 ** & $0.392 *$ \\
\hline $\mathrm{MgO}$ & & & & & & & 1 & 0.185 & 0.094 & $0.532 * *$ & $0.394 *$ \\
\hline $\mathrm{CaO}$ & & & & & & & & 1 & 0.127 & -0.163 & -0.124 \\
\hline${ }^{226} \mathrm{Ra}$ & & & & & & & & & 1 & -0.049 & 0.269 \\
\hline${ }^{232} \mathrm{Th}$ & & & & & & & & & & 1 & $0.536^{* *}$ \\
\hline${ }^{40} \mathrm{~K}$ & & & & & & & & & & & 1 \\
\hline
\end{tabular}

** Correlation is significant at the 0.01 level (2-tailed). ${ }^{*}$ Correlation is significant at the 0.05 level (2-tailed).

On the other hand, ${ }^{226}$ Ra shows no relation with soil characteristics or ${ }^{232} \mathrm{Th}$ and ${ }^{40} \mathrm{~K}$; similar results were recorded by Ribeiro et al. [21] and Gad et al. [16]. The notable lack of significant correlation or association between ${ }^{226} \mathrm{Ra}$ and each of ${ }^{232} \mathrm{Th}$ and ${ }^{40} \mathrm{~K}$ suggests that these radionuclides originated from different sources, and ${ }^{226} \mathrm{Ra}$ might have originated from the industrial activity in the area and accumulated by atmospheric deposition [16].

\subsection{Radiation Hazard}

Table 5 shows the calculated results of the radiological parameters for the considered samples. $\mathrm{Ra}_{\mathrm{eq}}$ was introduced to define uniformity with respect to radiation exposure due to these naturally occurring radionuclides [1,37]. The calculated $\mathrm{Ra}_{\mathrm{eq}}$ values vary from 22.902 to $121.708 \mathrm{~Bq} \mathrm{~kg}^{-1}$ (mean $69.052 \mathrm{~Bq} \mathrm{~kg}^{-1}$ ). These values are far lower than the recommended maximum value of $370 \mathrm{~Bq} \mathrm{~kg}^{-1}[1,37]$. The $\mathrm{H}_{\mathrm{ex}}$ radiation hazard due to emitted gamma-rays ranges from 0.062 to 0.329 (0.186). In this study, all calculated values of $\mathrm{H}_{\mathrm{ex}}$ are lower than the safety limit of one [38], which is considered negligible. 


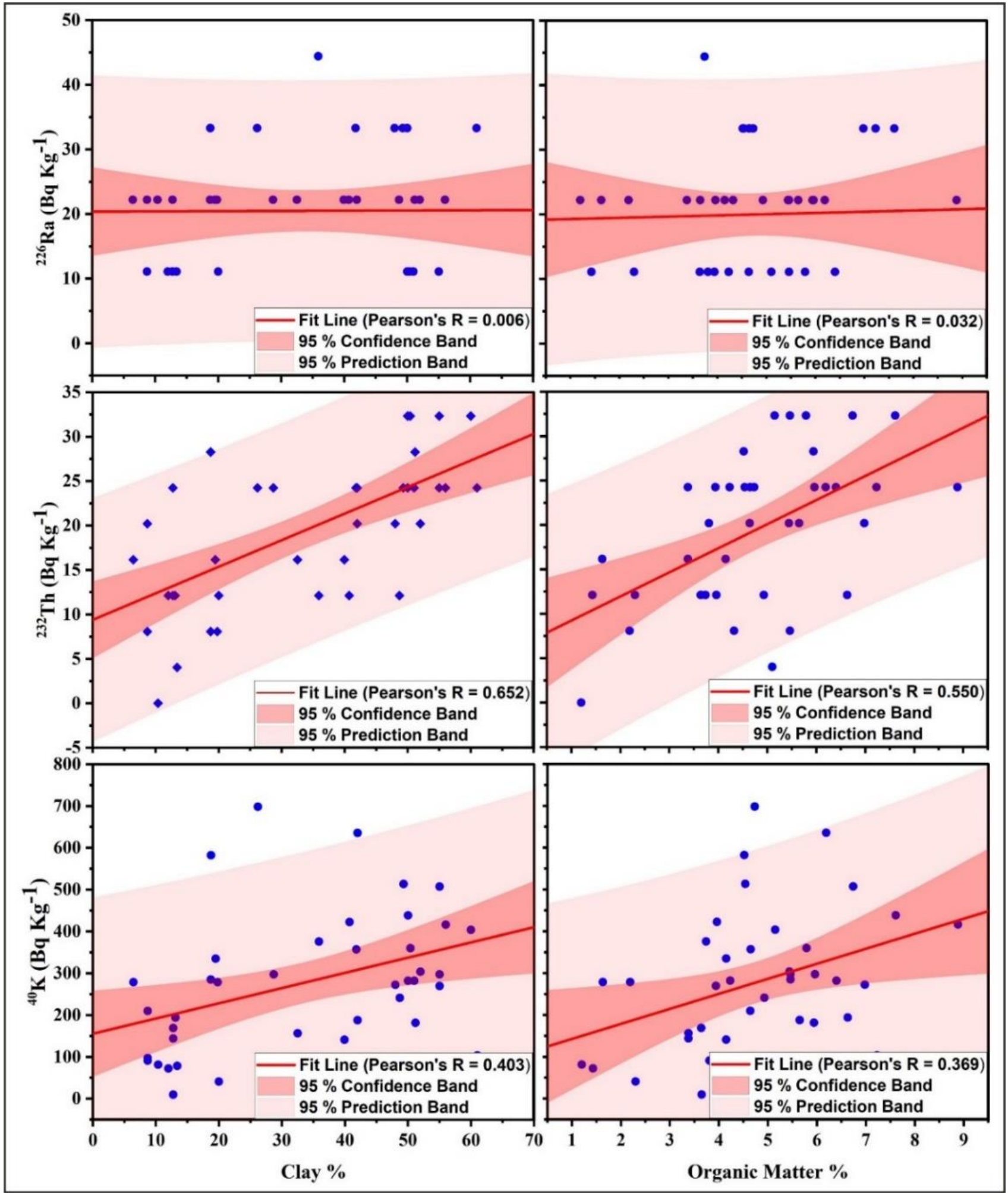

Figure 6. Scatter plots showing the relationships between ${ }^{226} \mathrm{Ra},{ }^{232} \mathrm{Th}$, and ${ }^{40} \mathrm{~K}$ and the clay and organic matter contents $\%$. 


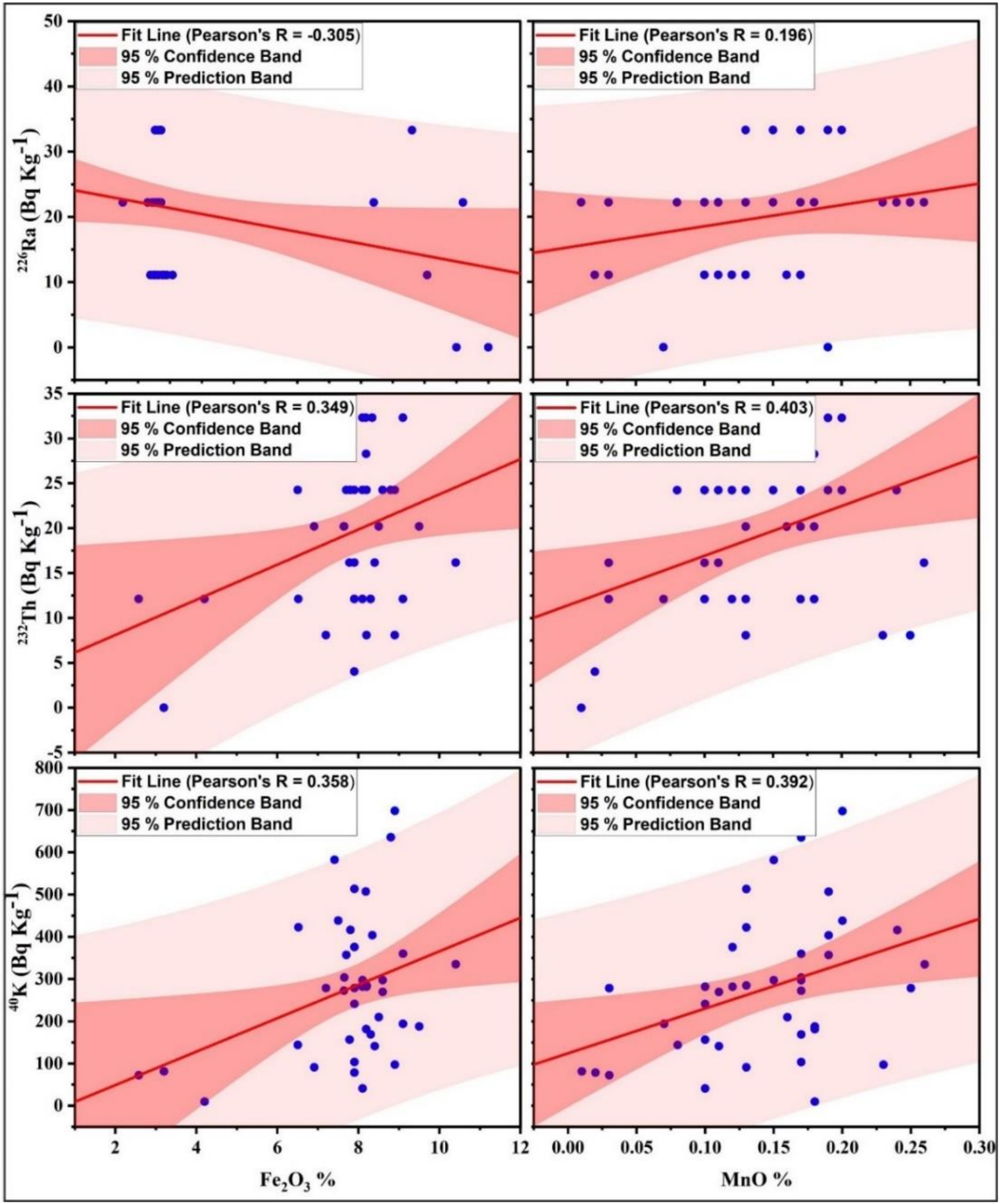

Figure 7. Scatter plots showing the relationships between ${ }^{226} \mathrm{Ra},{ }^{232} \mathrm{Th}$, and ${ }^{40} \mathrm{~K}$, and Fe and Mn oxides $\%$. 
Table 5. Calculated radiological parameters.

\begin{tabular}{ccccccc}
\hline & & $\mathbf{R a}_{\mathbf{e q}}$ & $\mathbf{H}_{\mathbf{e x}}$ & $\mathbf{D}$ & AEDE & ELCR $\times \mathbf{1 0}^{\mathbf{3}}$ \\
\hline \multirow{2}{*}{ All } & Min & 22.902 & 0.062 & 10.831 & 0.013 & 0.046 \\
Samples & Max & 121.708 & 0.329 & 59.132 & 0.073 & 0.254 \\
$\mathbf{N}=\mathbf{4 0}$ & Mean & 69.052 & 0.186 & 32.501 & 0.039 & 0.139 \\
& Std. D. & 24.984 & 0.067 & 12.094 & 0.015 & 0.052 \\
\hline
\end{tabular}

D values range from 10.831 to $59.132 \mathrm{nGy} \mathrm{h}^{-1}$ (mean $32.501 \mathrm{nGy} \mathrm{h}^{-1}$ ). At only one site, the recorded $\mathrm{D}$ value is above the worldwide average of $57 \mathrm{nGy} \mathrm{h}{ }^{-1}$ for external outdoor exposures [1]. Figure 8 shows the contributions of ${ }^{226} \mathrm{Ra},{ }^{232} \mathrm{Th}$, and ${ }^{40} \mathrm{~K}$ activity concentrations to the calculated D values in each soil sample site. It is evident that the contribution of these radionuclides varies from one site to another.

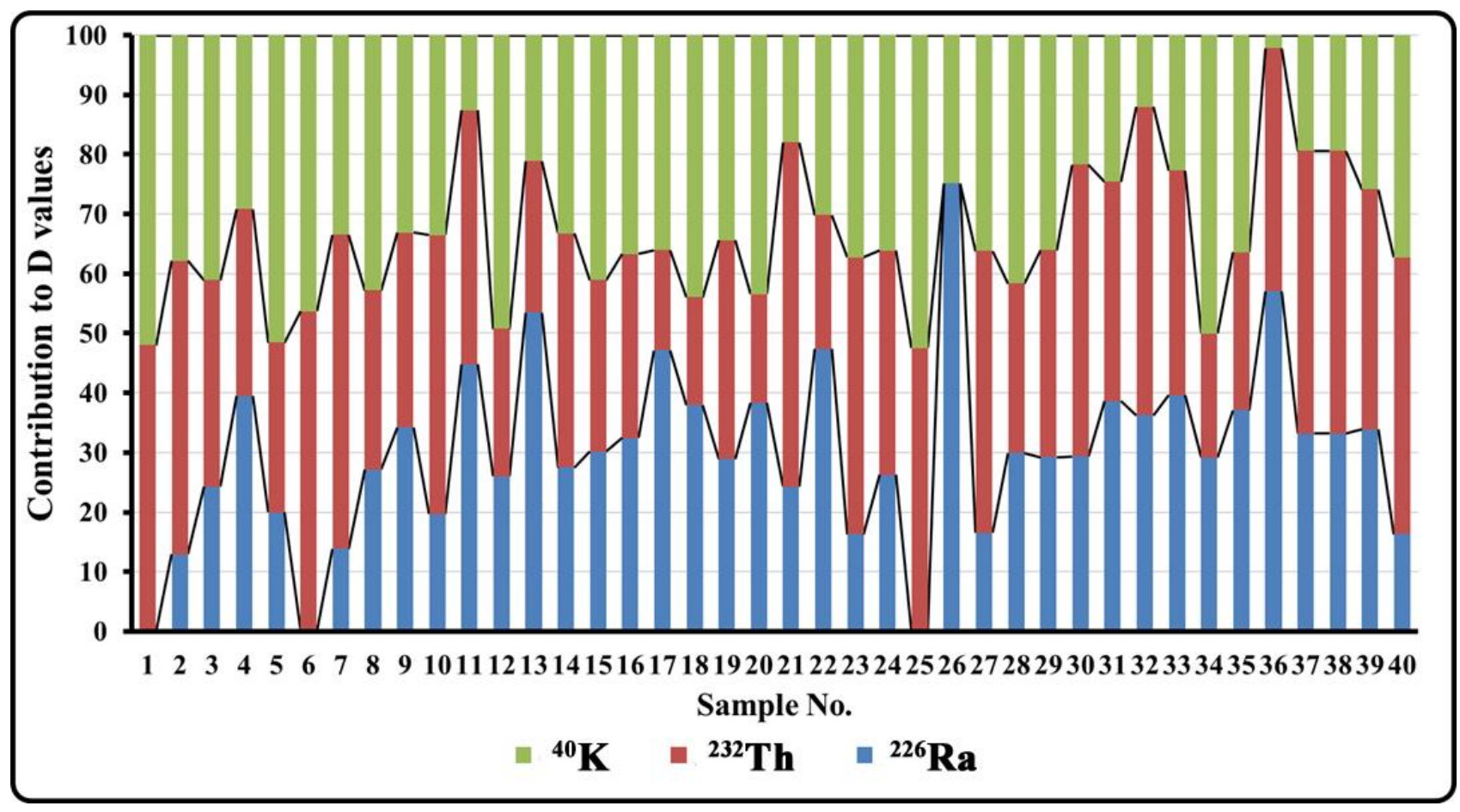

Figure 8. The contributions of ${ }^{226} \mathrm{Ra},{ }^{232} \mathrm{Th}$, and ${ }^{40} \mathrm{~K}$ to $\mathrm{D}$ values.

AEDE with outdoor occupation factors of $0.2\left(4.8 \mathrm{~h} \mathrm{~d}^{-1}\right)$ for inhabitants ranges from 0.013 to $0.073 \mathrm{mSv}_{\text {year }}{ }^{-1}$ (mean $0.039 \mathrm{mSv}$ year ${ }^{-1}$ ). The AEDE calculated values surpass the worldwide average of $0.07 \mathrm{mSv}$ year ${ }^{-1}$ [1] in only one sampling site. ELCR calculated values range from $0.046 \times 10^{-3}$ to $0.254 \times 10^{-3}$ (mean $0.139 \times 10^{-3}$ ). These values are lower than the world's average of $0.29 \times 10^{-3}[4,39]$.

The GIS-based spatial maps of the calculated radiological parameters are presented in Figure 9. High values of these parameters are recorded in the northeastern part of the study area over the agricultural land and near the intensive industrial activity. 


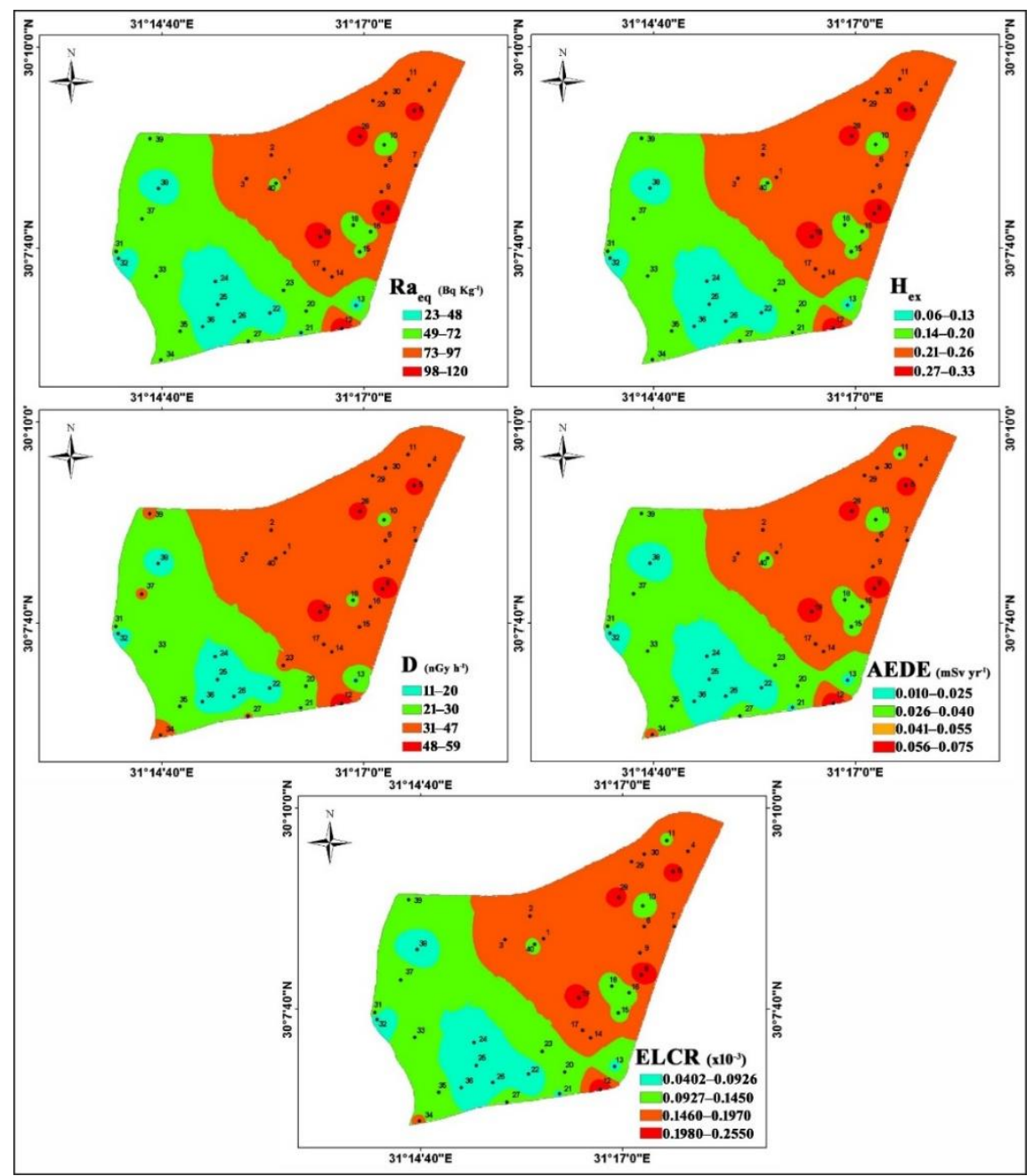

Figure 9. Spatial distribution maps of radiological parameters.

\section{Conclusions}

The activity concentrations of naturally occurring radionuclides $\left({ }^{226} \mathrm{Ra},{ }^{232} \mathrm{Th}\right.$, and ${ }^{40} \mathrm{~K}$ ) in forty soil samples from Shoubra El Kheima in the South Nile Delta have been determined using gamma-ray spectrometry. The measured activity concentrations of natural radionuclides are in the order ${ }^{40} \mathrm{~K}>{ }^{226} \mathrm{Ra}>{ }^{232} \mathrm{Th}$ in urban and industrial soil, and ${ }^{40} \mathrm{~K}>{ }^{232} \mathrm{Th}>{ }^{226} \mathrm{Ra}$ in agricultural soil. The obtained results for mean values of ${ }^{226} \mathrm{Ra}$ and ${ }^{40} \mathrm{~K}$ are higher than the world average in $20 \%$ of the samples. ${ }^{232} \mathrm{Th}$ and ${ }^{40} \mathrm{~K}$ distributions are influenced by the soil $\mathrm{OM}$ and clay content and scavenger metals' oxides. ${ }^{226} \mathrm{Ra}$ has no relation to soil characteristics or ${ }^{232} \mathrm{Th}$ and ${ }^{40} \mathrm{~K}$. The industrial activity and agricultural practices in the study area have caused a small increase in ${ }^{226} \mathrm{Ra}$ and ${ }^{40} \mathrm{~K}$ activity concentrations.

The selected soils are considered radiologically safe based on the calculated radiological hazard parameters that show either comparable or lower values than the world's average values or the relevant safety criteria. It can be deduced that despite the intensive industrial activities within the area, the spontaneous natural radiation coming from the soil is normal and does not cause any significant radiological hazard to the public. It is recommended that the natural radioactivity of soil in this area be monitored periodically to avoid unnecessary radiation exposure to the public.

Author Contributions: Conceptualization, A.M., Y.H.D., A.G., M.S.E.-B., and R.O.; methodology, R.O. and A.G.; software, R.O. and A.G.; validation, R.O. and A.G.; formal analysis, R.O. and A.G.; investigation, R.O., A.M., and A.G.; resources, R.O. and A.G.; data curation, A.G. and R.O.; writing- 
original draft preparation, A.G. and R.O.; writing-review and editing, Y.H.D. and A.M.; supervision, A.M., Y.H.D., M.S.E.-B., and A.G.; project administration, A.S., Y.H.D., and A.G.; funding acquisition, A.S. All authors have read and agreed to the published version of the manuscript.

Funding: This research was funded by the Science and Technology Development Fund (STDF), Egypt, Project ID: 41628.

Institutional Review Board Statement: Not applicable.

Informed Consent Statement: Not applicable.

Acknowledgments: This research was funded by the Science and Technology Development Fund (STDF), Egypt, Project ID: 41628. The authors would like to acknowledge the laboratory facilities offered by the National Research Center and Nuclear Materials Authority of Egypt. The authors wish to thank Osman M. (Nuclear Materials Authority) for his technical assistance during gamma-ray spectrometry analysis.

Conflicts of Interest: The authors declare no conflict of interest. The funders had no role in the design of the study; in the collection, analyses, or interpretation of data; in the writing of the manuscript; or in the decision to publish the results.

\section{References}

1. UNSCEAR. Sources and Effects of Ionizing Radiation, Report to the General Assembly with Scientific Annexes; United Nation: New York, NY, USA, 2000.

2. Missimer, T.M.; Teaf, C.; Maliva, R.G.; Danley-Thomson, A.; Covert, D.; Hegy, M. Natural radiation in the rocks, soils, and groundwater of Southern Florida with a discussion on potential health impacts. Int. J. Environ. Res. Public Health 2021, 16, 1793. [CrossRef] [PubMed]

3. Kang, T.; Park, W.; Han, T.; Bong, K.M.; Kim, K. Natural and artificial radioactivity in volcanic ash soils of Jeju Island, Republic of Korea, and assessment of the radiation hazards: Importance of soil properties. J. Radioanal. Nucl. Chem. 2020, 323, 1113-1124. [CrossRef]

4. UNSCEAR. Sources and Effects of Ionizing Radiation, Report to the General Assembly with Scientific Annexes; United Nation: New York, NY, USA, 2008.

5. Pal, R.; Patra, A.C.; Bakshi, A.K.; Dhabekar, B.; Reddy, P.J.; Sengupta, P.; Sapra, B.K. Investigations on baseline levels for natural radioactivity in soils, rocks, and lakes of Larsemann Hills in East Antarctica. Environ. Monit. Assess. 2021, 193, 822. [CrossRef] [PubMed]

6. Yehia, M.; Baghdady, A.; Howari, F.M.; Awad, S.; Gad, A. Natural radioactivity and groundwater quality assessment in the northern area of the Western Desert of Egypt. J. Hydrol. Reg. Stud. 2017, 12, 331-344. [CrossRef]

7. Ndour, O.; Thiandoume, C.; Traore, A.; Cagnat, X.; Diouf, P.M.; Ndeye, M.; Ndao, A.S.; Tidjani, A. Assessment of natural radioactivity and its radiological hazards in several types of cement used in Senega. SN Appl. Sci. 2020, 2, 2078. [CrossRef]

8. Caridi, F.; Testagrossa, B.; Acri, G. Elemental composition and natural radioactivity of refractory materials. Environ. Earth Sci. 2021, 80, 170. [CrossRef]

9. Massoud, E.; El-Taher, A.; Najam, L.A.; Elsaman, R. Ecological impacts of Assuit fertiliser factory in Upper Egypt: Environmental implications and spatial distribution of natural radionuclides. Int. J. Environ. Anal. Chem. 2021, 1-15. [CrossRef]

10. Garba, N.N.; Odoh, C.M.; Nasiru, R.; Saleh, M.A. Investigation of potential environmental radiation risks associated with artisanal gold mining in Zamfara State, Nigeria. Environ. Earth Sci. 2021, 80, 76. [CrossRef]

11. Hazou, E.; Zorko, B.; Dzagli, M.M.; Haliba, E.M.; Guembou, S.C.; Ndontchueng, M.M.; Tchakpele, P.K. Transfer from soil to grass and statistical analysis of naturally occurring radionuclides in soil from phosphate mining and processing sites in Maritime Region of Togo. Environ. Earth Sci. 2021, 80, 626. [CrossRef]

12. Abedin, M.J.; Karim, M.R.; Hossain, S.; Deb, N.; Kamal, M.; Miah, M.H.A.; Khandaker, M.U. Spatial distribution of radionuclides in agricultural soil in the vicinity of a coal-fired brick kiln. Arab. J. Geosci. 2019, 12, 236. [CrossRef]

13. Dinis, M.L.; Fiúza, A.; Góis, J.; Carvalho, J.S.; Castro, A.C. Assessment of natural radioactivity, heavy metals and particulate matter in air and soil around a coal-fired power plant-An integrated approach. Atmosphere 2021, 12, 1433. [CrossRef]

14. Majeed, K.F.; Salama, E.; Elfki, S.A.; Al-Bakhat, Y.M. Natural radioactivity assessment around the petroleum-producing areas of The-Qar province, Iraq. Environ. Earth Sci. 2021, 80, 64. [CrossRef]

15. Baghdady, A.; Awad, S.; Gad, A. Assessment of metal contamination and natural radiation hazards in different soil types near iron ore mines, Bahariya Oasis, Egypt. Arab. J. Geosci. 2018, 11, 506. [CrossRef]

16. Gad, A.; Saleh, A.; Khalifa, M. Assessment of natural radionuclides and related occupational risk in agricultural soil, southeastern Nile Delta, Egypt. Arab. J. Geosci. 2019, 12, 188. [CrossRef]

17. Younis, H.; Wasim, B.; Qureshi, A.A.; Ali, M.; Ahmad, F.; Mehboob, K.; Ajaz, M.; Hussain, K. Determination of radioactivity levels in the virgin and fertilized soil samples of Rawalpindi District, Pakistan. Iran. J. Sci. Technol. Trans. Sci. 2021, 45, 1085-1095. [CrossRef] 
18. Luevano-Gurrola, S.; Perez-Tapia, A.; Pinedo-Alvarez, C.; Carrillo-Flores, J.; Montero-Cabrera, M.E.; Renteria-Villalobos, M. Lifetime effective dose assessment based on background outdoor gamma exposure in Chihuahua City, Mexico. Int. J. Environ. Res. Public Health 2015, 12, 12324-12339. [CrossRef]

19. Aghdam, M.M.; Crowley, Q.; Rocha, C.; Dentoni, V.; Da Pelo, S.; Long, S.; Savatier, M. A study of natural radioactivity levels and radon/thoron release potential of bedrock and soil in Southeastern Ireland. Int. J. Environ. Res. Public Health 2021, 18, 2709. [CrossRef]

20. Belyaeva, O.; Movsisyan, N.; Pyuskyulyan, K.; Sahakyan, L.; Tepanosyan, G.; Saghatelyan, A. Yerevan soil radioactivity: Radiological and geochemical assessment. Chemosphere 2021, 265, 129173. [CrossRef]

21. Ribeiro, F.C.; Lauria, D.C.; Rio, M.A.; da Cunha, F.G.; Sousa, W.O.; Lima, E.M.; Franzen, M. Mapping soil radioactivity in the Fernando de Noronha archipelago, Brazil. J. Radioanal. Nucl. Chem. 2017, 311, 577-587. [CrossRef]

22. Ahmed, N.K.; El-Arabi, A.M. Natural radioactivity in farm soil and phosphate fertilizer and its environmental implications in Qena governorate, Upper Egypt. J. Environ. Radioact. 2005, 84, 51-64. [CrossRef]

23. Belivermis, M.; Kılıç, Ö.; Çotuk, Y.; Topcuoğlu, S. The effects of physicochemical properties on gamma emitting natural radionuclide levels in the soil profile of Istanbul. Environ. Monit. Assess. 2010, 163, 15-26. [CrossRef] [PubMed]

24. Mostafa, A.M.; Uosif, M.A.; Elsaman, R.; Alrowaili, Z.A.; Moustafa, E. The dependence of natural radioactivity levels and its radiological hazards on the texture of agricultural soil in Upper Egypt. Environ. Earth Sci. 2020, 79, 228. [CrossRef]

25. Issa, S.A. Radiometric assessment of natural radioactivity levels of agricultural soil samples collected in Dakahlia, Egypt. Radiat. Prot. Dosim. 2013, 156, 59-67. [CrossRef]

26. El-Gamal, H.; Hussien, M.T.; Saleh, E.E. Evaluation of natural radioactivity levels in soil and various foodstuffs from Delta Abyan, Yemen. J. Radiat. Res. Appl. Sci. 2019, 12, 226-233. [CrossRef]

27. Ugbede, F.O.; Osahon, O.D.; Agbalagba, E.O. Radiological risk assessment of ${ }^{238} \mathrm{U},{ }^{232} \mathrm{Th}$ and ${ }^{40} \mathrm{~K}$ in soil and their uptake by rice cultivated in CAS paddy environment of Abakaliki, Nigeria. Chem. Afr. 2021, 4, 691-701. [CrossRef]

28. Monged, M.H.; Abu Khatita, A.M.; El-Hemamy, S.T.; Sabet, H.S. Environmental assessment of radioactivity levels and radiation hazards in soil at North Western-Mediterranean Sea coast, Egypt. Environ. Earth Sci. 2020, 79, 386. [CrossRef]

29. Khalifa, M.; Gad, A. Assessment of heavy metals contamination in agricultural soil of southwestern Nile Delta, Egypt. Soil Sediment Contam. Int. J. 2018, 27, 619-642. [CrossRef]

30. Osman, R.; Melegy, A.; Dawood, Y.; Gad, A. Distribution of some potentially toxic heavy metals in the soil of Shoubra El Kheima, Egypt. Egypt. J. Chem. 2021, 64, 1965-1980. [CrossRef]

31. Van Reeuwijk, L.P. Procedures for Soil Analysis, 6th ed.; International Soil Reference and Information Centre: Wageningen, The Netherlands, 2002.

32. Lewis, D.W.; McConchie, D. Analytical Sedimentology; Springer: Amsterdam, The Netherlands, 1994.

33. International Atomic Energy Agency (IAEA). Intercomparison Runs Reference Manuals; AQCS: Vienna, Austria, 1995.

34. Ibraheem, A.A.; El-Taher, A.; Alruwaili, H.M. Assessment of natural radioactivity levels and radiation hazard indices for soil samples from Abha, Saudi Arabia. Results Phys. 2018, 11, 325-330. [CrossRef]

35. Abbasi, A.; Kurnaz, A.; Turhan, S.; Mirekhtiary, F. Radiation hazards and natural radioactivity levels in surface soil samples from dwelling areas of North Cyprus. J. Radioanal. Nucl. Chem. 2020, 324, 203-210. [CrossRef]

36. Kavasara, M.; Vinutha, P.R.; Kaliprasad, C.S.; Narayana, Y. Studies on the dependence of natural radioactivity on clay minerals of soils in Davanagere district of Karnataka, India. J. Radioanal. Nucl. Chem. 2021, 330, 1461-1471. [CrossRef]

37. Beretka, J.; Mathew, P.J. Natural radioactivity of Australian building materials, industrial wastes and by-products. Health Phys. 1985, 48, 87-95. [CrossRef]

38. ECRP (European Commission Radiation Protection). Radiological Protection Principles Concerning the Natural Radioactivity of Building Materials; 112; European Comissision: Brussels, Belgium, 1999.

39. Taskin, H.; Karavus, M.; Ay, P.; Topuzoglu, A.; Hindiroglu, S.; Karahan, G. Radionuclide concentrations in soil and lifetime cancer risk due to the gamma radioactivity in Kirklareli, Turkey. J. Environ. Radioact. 2009, 100, 49-53. [CrossRef] [PubMed]

40. ICRP (International Commission on Radiological Protection). Recommendations of the International Commission on Radiological Protection. In ICRP Publication 60; Pergamon Press Ann ICRP: Oxford, UK, 1990.

41. USDA. Soil Taxonomy: A Basic System of Soil Classification for Making and Interpreting Soil Surveys, Handbook No. 436; US Department of Agriculture: Washington, WA, USA, 1999.

42. Melegy, A.A.; El-Agami, N.L. Factors controlling the chemistry and mineralogy of selected soils types of the Czech Republic and Egypt. Bull. Geosci. 2004, 79, 71-79.

43. Tabar, E.; Yakut, H.; Saç, M.M.; Taşköprü, C.; İçhedef, M.; Kuş, A. Natural radioactivity levels and related risk assessment in soil samples from Sakarya, Turkey. J. Radioanal. Nucl. Chem. 2017, 313, 249-259. [CrossRef]

44. Kekelidze, N.; Jakhutashvili, T.; Tutberidze, B.; Tulashvili, F.; Akhalkatsishvili, M.; Mtsariashvili, L. Radioactivity of soils in Mtskheta-Mtianeti region (Georgia). Ann. Agrar. Sci. 2017, 15, 304-311. [CrossRef]

45. IAEA (International Atomic Energy Agency). The Environmental Behaviour of Radium, revised ed.; IAEA-TRS 476; IAEA: Vienna, Austria, 2014

46. Wang, Z.; Ye, Y. Assessment of soil radioactivity levels and radiation hazards in Guangyao Village, South China. J. Radioanal. Nucl. Chem. 2021, 329, 679-693. [CrossRef] 
47. Mohammed, N.; Chanai, E.; Alkhorayef, M. The impact of the extensive use of phosphate fertilizers on radioactivity levels in farm soil and vegetables in Tanzania. J. Radioanal. Nucl. Chem. 2016, 307, 2373-2379. [CrossRef]

48. Kasumović, A.; Adrović, F.; Kasić, A.; Hankić, E. Natural radioactivity and radiation hazards assessment of soil samples from the area of Tuzla and Lukavac, Bosnia and Herzegovina. Isot. Environ. Health Stud. 2015, 51, 469-477. [CrossRef]

49. Hamideen, M.S. Correlations study between environmental radioactivity concentrations and some health risk indicators of soil samples in Amman city, Jordan. Int. J. Environ. Anal. Chem. 2022, 102, 380-390. [CrossRef]

50. Garba, N.N.; Ramli, A.T.; Saleh, M.A.; Gabdo, H.T. Natural radioactivity and associated radiation hazards in soil of Kelantan, Malaysia. Hum. Ecol. Risk Assess. Int. J. 2019, 25, 1707-1717. [CrossRef]

51. Külahcı, F.; Aközcan, S.; Günay, O. Monte Carlo simulations and forecasting of Radium-226, Thorium-232, and Potassium-40 radioactivity concentrations. J. Radioanal. Nucl. Chem. 2020, 324, 55-70. [CrossRef] 